\title{
SYNE1 wt Allele
}

National Cancer Institute

\section{Source}

National Cancer Institute. SYNE1 wt Allele. NCI Thesaurus. Code C150328.

Human SYNE1 wild-type allele is located in the vicinity of $6 q 25.2$ and is approximately 516 $\mathrm{kb}$ in length. This allele, which encodes nesprin-1 protein, is involved in the subcellular position of the nucleus. Mutation of the gene is associated with autosomal recessive spinocerebellar ataxia 8. 